\title{
MICROBIAL GUT FLORA OF A FRESHWATER FISH GARRA MULLYA (SYKES) FROM MUTHA RIVER, NORTHERN WESTERN GHATS, INDIA
}

\author{
B.S. Rudresh ${ }^{1 *}$, N. Dahanukar ${ }^{2}$, G.M. Watve ${ }^{2}$ and N.S. Renukaswamy ${ }^{3}$ \\ ${ }^{1}$ J.C.B.M. Collage, Sringere, Chikmaglur, Karnataka, India \\ ${ }^{2}$ Department of Microbiology, Abasaheb Garware College, Pune, India \\ ${ }^{3}$ Central Coffee Research Institute, Chikmagalur, India \\ *Email: rudresh21@gmail.com
}

\begin{abstract}
Preliminary exploration of gut flora of Garra mullya (Sykes) revealed nineteen bacterial strains showing wide diversity of enzyme production, morphological and biochemical characteristics. The factors which govern the diversity assessed through principal component analysis and correspondence analysis show that isolated strain have adaptation to utilization of variety resources like citrate and sugar, and also show tolerance to variety of environmental conditions like $\mathrm{pH}$, salt, and bile in invitro condition.
\end{abstract}

Key words: Gut flora, bacterial diversity, Garra mullya.

\section{INTRODUCTION}

Garra mullya (Sykes) is a fresh water fish commonly encountered in the Indian subcontinent and is very common throughout the Western Ghats of India. It is also a common fish in Mutha river, Pune and has a good population density (Kharat et al. 2000). It is commonly sold as a food fish in the local market and is known by the name "Mullya". According to Talwar and Jhingran (1991), Garra mullya is classified under the Order Cypriniforme, Family Cyprinidae and Sub-family Garrinae. It has a moderate commercial value. It attains a length of $10 \mathrm{~cm}$ and weighs about $25 \mathrm{~g}$. Even though the food and feeding habits of the fish are not studied explicitly, the preliminary study of gut dissection show that the food of Garra mullya comprises of algae, phytoplankton and detritus matter.
For different experimental purposes, the microbial gut flora of fish has been studied by several workers. This includes, description of microbial spoilage (Joseph et al. 1988), relation between environment and fish micro flora (Horsely 1973), monitoring change in fish form (Allen et al. 1983), microbial flora as food of fish (Kamjunke et al. 2002), microbial flora help in production of enzymes (Bairagi et al. 2002) and antibiotic resistance profile of indigenous flora (Spanggaard et al. 1993). The micro flora of reared fish has also been studied as a source of protection against diseases (Sissons et al. 1989). For all these reasons, study of bacterial flora of the gut is important. In this study we have analyzed the bacterial gut flora of a freshwater fish Garra mullya (Sykes). 
The aim of the study was to isolate the bacterial gut flora, study on the enzymes produced by the bacteria, to study morphological and biochemical characterization of isolated bacteria, and to analyze the diversity of bacteria based on morphological and biochemical characteristics.

\section{MATERIALS AND METHODS}

Collection of fish: Fresh water fish Garra mullya was collected from Mutha river $\left(18^{\circ} 31^{\prime} \mathrm{N}\right.$ and 7351' E), Pune, northern Western Ghats. The fresh fish were bought from the local market at Verje.

Isolation of gut flora: The fish was surface sterilized with alcohol $(70 \%)$ and the gut was removed by dissection. The gut was immersed in sterile saline. Presence and type of bacteria were checked by performing wet mount of the saline suspension. Bacterial suspension was streaked on nutrient agar media. The plates were incubated at $37^{\circ} \mathrm{C}$ for $24 \mathrm{~h}$.

Morphological characterization: Morphological characterization of colony was done with the help of compound microscope. The characters observed include-colony size, shape, margin, elevation, colour, opacity, consistency, gram staining and motility.

Biochemical characterization: The biochemical characterization of the isolated bacteria include sugar utilization, respiration type, salt tolerance, $\mathrm{pH}$ tolerance, bile tolerance, lactose fermentation, amylase production, catalase production, oxidase production, citrate utilization, indole production, methyl red test and Voges prousker test.

\section{RESULTS AND DISCUSSION}

Nineteen bacterial strains were isolated from the gut of Garra mullya. The colony characters of the isolates showed varied morphological characters. Isolate 2 was the only motile organism among the 19 isolates. Five were Gram positive and among these three were cocci, two were bacillococci and the remaining 14 were Gram negative. Among these, two were round nine were bacillococci and three bacilli (Table 1).

The biochemical characterization of the bacterial isolates is given in Table 2. It has been observed that the bacteria isolated from the gut of Garra mullya were aerobic and showed positive results for catalase activity. The relationship between various bacterial isolates according to their biochemical characters is shown in Fig. 1 and the Principal component analysis and correspondence analysis are given in Fig. 2.

Jaccard Cluster Analysis (Group Average Link)

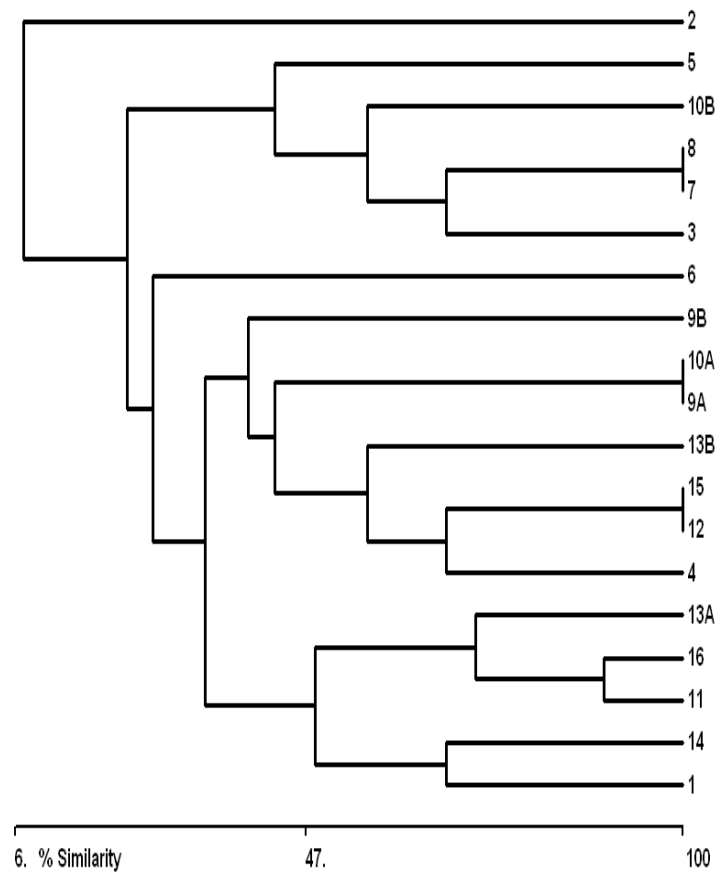

Fig. 1. Biochemical relationship between different bacterial isolates found in the gut of Garra mullya. 

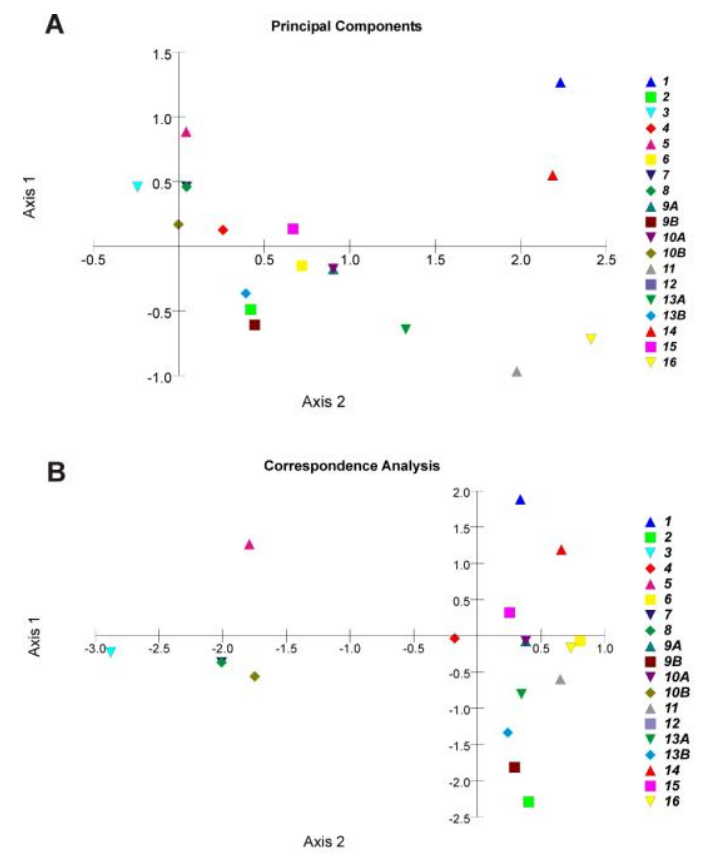

Fig. 2. Principle component analysis (A) and Correspondence analysis (B) of the bacterial isolates, based on biochemical characters.

The initial analysis suggests that the isolates belong to the order Eubacteriales as per the Bergey's Manual of Deterministic Bacteriology (Holt 2000). The isolates are suspected to be from the families Acromobacteraceae or Enterobacteriaceae, nonetheless more analysis is essential for the classification of the isolates. The isolates 2, 9B, 13A, 13B and 16 showed amylase production. It will be interesting to study these isolates and their relationship with the fish as it is known that some bacterial species complement their fish host by producing enzymes that help the fish to consume and digest food (Bairagi et al. 2002).
Seven bacterial isolates out of a total of 19 could grow on the McConkey agar plates, of which only three were lactose fermentative. Even though this might be an indication that these species could be from family Enterobacteriaceae it needs conformation. As only Seven species are bile tolerant we suspect that these could be localized in the area near the gut of the fish. The remaining 11 isolates could be restricted to the distant parts of the intestine.

Out of the 19 isolates, three isolates had interesting morphology. These isolates of bacteria are normal gut flora of Garra mullya. If these species are indeed common in this fish and do not occur in other fish inhibiting the habitats of Garra mullya, there is a possibility to design a protocol to estimate the number of Garra mullya in the water just by looking at the count of these bacteria. The concept is hypothetical but not impossible.

The dendrogram (Fig. 2) based on the biochemical analysis suggests that there is a wide diversity in the organisms found in the Garra mullya gut. The factors which govern this diversity can be speculated from the analysis of PCA (Fig. 3A) and CCA (Fig. 3B) analysis. The patterns in PCA and CCA both are governed by biochemical tests involved in utilization and tolerance characterization. This indicates that adaptation to a variety of resource utilization patterns (citrate and sugar utilization in our tests) and tolerance to a variety of environmental conditions (salt, $\mathrm{pH}$ and bile) governs the biochemical diversity of Garra mullya bacterial flora. 
Table1. Colony characters of the isolates.

\begin{tabular}{|c|c|c|c|c|c|c|c|c|c|c|}
\hline SN & Isolates & $\begin{array}{l}\text { Size } \\
(\mathbf{m m})\end{array}$ & Shape & Margin & Elevation & Colour & Opacity & Consistency & $\begin{array}{c}\text { Gram } \\
\text { Staining }\end{array}$ & Motility \\
\hline 1 & 1 & 1.5 & Round & Smooth & Flat & White & Opaque & Moist & -Ve R & Non motile \\
\hline 2 & 2 & 2.0 & Round & Rough & Flat & White & Opaque & Moist & -Ve R & Motility \\
\hline 3 & 3 & 1.5 & Round & Smooth & Flat & White & Opaque & Moist & $+\mathrm{Ve} \mathrm{Bc}$ & Non motile \\
\hline 4 & 4 & 2.0 & Round & Smooth & Flat & White & Opaque & Moist & $-\mathrm{Ve} \mathrm{Bc}$ & Non motile \\
\hline 5 & 5 & 2.5 & Round & Smooth & Flat & White & Opaque & Moist & $+\mathrm{Ve} \mathrm{Bc}$ & Non motile \\
\hline 6 & 6 & 1.5 & Round & Smooth & Flat & White & Opaque & Moist & $-\mathrm{Ve} \mathrm{Bc}$ & Non motile \\
\hline 7 & 7 & 2.0 & Round & Smooth & Flat & White & Opaque & Moist & $+\mathrm{Ve} \mathrm{C}$ & Non motile \\
\hline 8 & 8 & 1.0 & Round & Smooth & Low convex & Crème white & Translucent & Moist & $+\mathrm{Ve} C$ & Non motile \\
\hline 9 & $9 \mathrm{~A}$ & 1.0 & Round & Smooth & Flat & White & Opaque & Moist & $-\mathrm{Ve} \mathrm{Bc}$ & Non motile \\
\hline 10 & 9B & 2.0 & Oval & Rough & Flat & White & Opaque & Moist & -Ve B & Non motile \\
\hline 11 & $10 \mathrm{~A}$ & 2.0 & Round & Smooth & Flat & White & Opaque & Moist & $-\mathrm{Ve} \mathrm{Bc}$ & Non motile \\
\hline 12 & $10 \mathrm{~B}$ & 2.5 & Round & Rough & Low convex & Yellow & Non opaque & Dry & $+\mathrm{Ve} C$ & Non motile \\
\hline 13 & 11 & 1.0 & Round & Smooth & Flat & White & Opaque & Moist & $-V e B$ & Non motile \\
\hline 14 & 12 & 1.0 & Round & Smooth & Flat & White & Opaque & Moist & -Ve B & Non motile \\
\hline 15 & $13 \mathrm{~A}$ & 3.0 & Round & Rough & Concave & White & Nonopaque & Dry & $-\mathrm{Ve} \mathrm{Bc}$ & Non motile \\
\hline 16 & 13B & 1.5 & Round & Rough & Flat & White & Opaque & Moist & $-\mathrm{Ve} \mathrm{Bc}$ & Non motile \\
\hline 17 & 14 & 1.5 & Round & Smooth & Flat & White & Opaque & Moist & $-\mathrm{Ve} \mathrm{Bc}$ & Non motile \\
\hline 18 & 15 & 1.0 & Round & Smooth & Flat & White & Opaque & Moist & $-\mathrm{Ve} \mathrm{Bc}$ & Non motile \\
\hline 19 & 16 & 1.0 & Round & Smooth & Flat & White & Opaque & Moist & $-\mathrm{Ve} \mathrm{Bc}$ & Non motile \\
\hline
\end{tabular}

Note: C-cocci, BC- bacillococci, B- bacilli.

Table 2. Biochemical characters of the isolates.

\begin{tabular}{|c|c|c|c|c|c|c|c|c|c|c|c|c|c|c|c|c|}
\hline $\begin{array}{l}\frac{\tilde{\sigma}}{0} \\
\frac{\pi}{0}\end{array}$ & 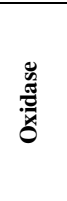 & 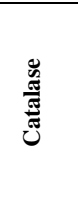 & 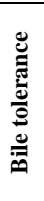 & 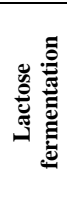 & 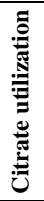 & 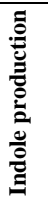 & 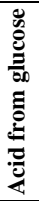 & $\frac{\overrightarrow{\mathrm{g}}}{\vec{s}}$ & 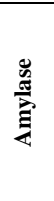 & 苍 & 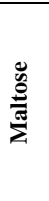 & 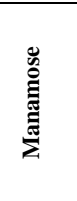 & $\frac{\ddot{y}}{\frac{\ddot{x}}{2}}$ & $\begin{array}{l}\overline{\mathscr{Z}} \\
\bar{Z} \\
0\end{array}$ & $\begin{array}{l}\bar{\Xi} \\
\bar{z} \\
0 \\
0\end{array}$ & $\begin{array}{l}\bar{\Xi} \\
\bar{z} \\
0 \\
\text { in }\end{array}$ \\
\hline 1 & +++ & +++ & + & - & + & - & - & - & - & +++ & ++ & ++++ & - & +++ & ++ & + \\
\hline 4 & +++ & +++ & - & - & - & - & - & - & - & - & - & - & - & +++ & + & - \\
\hline 5 & +++ & +++ & - & - & - & - & - & - & - & - & + & - & - & ++ & + & - \\
\hline 6 & + & +++ & + & + & + & - & - & - & - & - & - & - & - & ++ & ++ & - \\
\hline 7 & + & ++ & - & - & - & - & - & - & - & - & - & - & - & ++ & + & + \\
\hline 8 & +++ & +++ & - & - & - & - & - & - & - & - & - & - & - & +++ & ++ & + \\
\hline $10 \mathrm{~B}$ & +++ & +++ & - & - & - & - & + & - & - & - & - & - & - & +++ & ++ & - \\
\hline 11 & +++ & +++ & + & + & + & - & + & - & + & - & - & - & - & ++ & ++ & + \\
\hline 12 & +++ & +++ & + & - & - & - & - & - & - & - & - & - & - & ++ & + & - \\
\hline $13 \mathrm{~A}$ & +++ & ++ & - & - & - & - & + & - & +++ & - & - & - & - & ++ & + & + \\
\hline $13 \mathrm{~B}$ & +++ & + & - & - & - & - & - & - & +++ & - & - & - & - & ++ & + & - \\
\hline 14 & +++ & +++ & + & - & + & - & + & - & - & ++ & - & +++ & - & +++ & ++ & + \\
\hline 15 & +++ & +++ & + & - & - & - & - & - & - & - & - & - & - & ++ & ++ & - \\
\hline 16 & +++ & +++ & + & + & + & - & + & - & ++ & ++ & - & - & - & +++ & ++ & + \\
\hline
\end{tabular}

Key: (-) Negative; (+) Positive; more positive signs indicates intensity of the results.

(VP)-Voges prousker. 


\section{REFERENCES}

Allen, D.A., B. Austin and R. Colwell. 1983. Numerical taxonomy of bacterial isolates associated with a fresh water fishery. J. Gen. Micro. biol. 129:2043-2062.

Bairagi, A., K.S. Ghosh, S.K. Kumarsen and A.K. Ray. 2002. Enzyme producing bacterial flora isolated from fish digestive tracts. Aqua. International 10( 2):109-121.

Holt, J.G. (ed.). 2000. Bergey's Manual of Detereminative Bacteriology $\left(7^{\text {th }}\right.$ edition), Lippincott Willions and Wilkins, Philadelphia, USA. 259 p.

Horsley, R.W. 1973. A review of the bacterial flora of teleosts and elasmobranchs, including methods for its analysis. J. Fish Biology 10:529-553.

Joseph, J., P.K. Surendran and P.A. Perigeen. 1988. Studies on iced storage of cultured rohu (Labeo rohita). Fish. Technol. 25:105-109.
Kamjunke, N., R. Mendonca, I. Hardewing and T. Mehner. 2002. Assimilation of different cyanobacteria as food and the consequences for internal energy stores of juvenile roach. J. Fish Biology 60(3):731-738

Karat, S.S., N. Dahanukar and R. Raut. 2000. Decline of freshwater fish of Pune urban area. J. Ecological Society 13/14:46-51.

Sissons, J.W. 1989. Potential of probiotic organism to prevent diarrhea and promote digestion in farm animals-A review. J. Sci. Food Agric. 49:1-13.

Spanggaard, B., I. Huber, J. Nielsen, T. Nielsen, K.F. Appel and L. Gram. 2000. The micro flora of rainbow trout intestine: a comparison of traditional and molecular identification. Aquaculture 182:1-15.

Talwar, P.K. and T. Jhingran. 1991. Inland Fishes of India. Oxford and IBH publications, Delhi, India. $256 \mathrm{p}$. 